\title{
Ion selective carbon paste electrodes based on ion pair formation for determination of Tetra-n-butyl ammonium bromide
}

\author{
Sally E.A. El-Ashery ${ }^{1 *}$, Eman Y.Z. Frag ${ }^{1}$, Mohamed G. Moussa ${ }^{1}$, Gehad G. Mohamed $^{1}$ \\ ${ }^{1}$ Chemistry Department, Faculty of Science, Cairo University, Giza, 12613, Egypt. \\ Received: 2 May 2018 /Accepted: 5 May 2018 \\ * Corresponding author: dr.sallyahmed@yahoo.com
}

\begin{abstract}
In this study, ion pairs formed between tetrabutyl ammonium bromide as surfactant and ion pairing agents as phosphotungetic acid (PTA), phosphomolybdic acid (PMA) and sodium tetraphenyl borate (NaTPB) have been used as electroactive materials for preparation of modified carbon paste electrodes (CPEs) selective to tetra-n-butyl ammonium bromide (TBAB) surfactant. Type and content of the different ion pairs on the performance of CPEs were studied. It was found that the best contents were, $15 \mathrm{mg}$ of TBA-TPB (electrode I), $15 \mathrm{mg}$ TBA-PTA (electrode II) and $6 \mathrm{mg}$ TBA-PMA (electrode III) ion pairs, which gave the best Nernstian slope values of 59.41 \pm 0.31 , $59.26 \pm 0.45$ and $59.95 \pm 0.35 \mathrm{mVdecade}^{-1}$, respectively. These fabricated electrodes exhibited suitable response to $\mathrm{TBAB}$ in a concentration range from $1.0 \times 10^{-6}$ to $1.0 \times 10^{-2} \mathrm{~mol} \mathrm{~L}^{-1}$ with lower detection limit of $1.0 \times 10^{-6} \mathrm{~mol} \mathrm{~L}^{-1}$. These fabricated electrodes exhibited fast response time of about 3, 7 and 6 s under working $\mathrm{pH}$ range of 3-8, 5-8 and 5-9 for electrodes I, II and III, respectively. The results obtained were satisfactory with excellent percentage recovery comparable and sometimes better than those obtained by other routine methods for the assay of TBAB surfactant.
\end{abstract}

Keywords: Modified carbon paste ion-selective electrodes, Tetrabutylammonium bromide, Calibration and method validation.

\section{Introduction}

Ion selective electrodes (ISEs) were one of the most widely used potentiometric sensors during laboratory analysis as well as in environmental monitoring, reaction control, biomedical measurements, and industrial analysis. ISEs were electrochemical sensors that allow potentiometric determination of the activity of certain ion in the presence of other ions in the sample solution ${ }^{[1-2]}$. Surfactants are compounds that lower the surface tension (or interfacial tension) between two liquids or between liquid and solid. The term surfactant is a blend of surface active agent. They are usually organic compounds that are amphiphilic, meaning they contain both hydrophobic groups (their tails) and hydrophilic groups (their heads). Also they are classified according to polar head group to a non-ionic surfactant has no charged groups in its head and the head of an ionic surfactant carries a net positive or negative charge. If the charge is negative, the surfactant is more specifically called anionic, if the charge is positive, it is called cationic. If the surfactant contains a head with two oppositely charged groups, it is termed zwitter ion [3]. The structure of Tetra-n-butylammonium bromide (TBAB) is given as shown in Figure (1). 


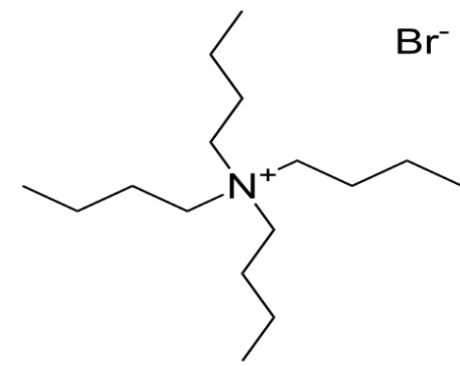

Figure (1). Chemical structure Tetra-n-butyl ammonium bromide.

Its molecular formula is $\mathrm{C}_{16} \mathrm{H}_{36} \mathrm{NBr}$ and its molecular weight is 322.38 $\mathrm{g} \mathrm{mol}{ }^{-1}$. TBAB has solid appearance and its melting point is $103.5^{\circ} \mathrm{C}\left(218.3^{\circ} \mathrm{F}\right)$. Also, it has toxic effects on humans and it is very hazardous in case of ingestion, or inhalation or in case of skin contact (irritant) ${ }^{[4]}$. Tetrabutylammonium bromide is a quaternary ammonium salt. It is an easily available ionic liquid. It participates as a catalyst during the solvent-free synthesis of biscoumarin and dihydropyrano[c]-chromene derivatives. It may be used as a catalyst in the synthesis of 3-thiobutyl-butanal, diethyl 2thiobutylsuccinate and 1-cyano-2thiobutylethane. There is no reported methods for quantitative determination of tetrabutylammonium bromide, so the main goal of our research was to fabricate a simple and sensitive carbon sensors for potentiometric determination of TBAB.

\section{Experimental}

\section{Reagents and materials}

All chemicals and reagents used were of analytical reagent grade and used as such without any further purification. Distilled water was used throughout all experiments. They included TBAB provided by Cornell Lab Company. Sodium fluoride and chloride salts of calcium, nickel, potassium, copper, zinc, chromium, aluminum, lead, manganese, ferrous, cadmium and cobalt were used as interfering materials and they were supplied by El-Nasr Company. To prepare ISE the following reagents were used: tricresylphosphate (TCP) and graphite powder (synthetic $1-2 \mu \mathrm{m}$ ) were supplied from Aldrich. Dioctylphthalate (DOP) was supplied from Sigma, while dioctyl sebacate (DOS) and dibutylphthalate (DBP) were supplied from Merck and 2-Florophenyl-2nitrophenyl ether (FPNPE) was supplied from BDH. Sodium tetraphenylborate (NaTPB)
$\left(\mathrm{C}_{6} \mathrm{H}_{5}\right)_{4} \mathrm{BNa}$ was purchased from Sigma-Aldrich, Germany, o-nitrophenyloctylether (o-NPOE), phosphotungstic acid (PTA; $\mathrm{H}_{3}\left[\mathrm{PW}_{12} \mathrm{O}_{40}\right]$ ), phosphomolybdic acid (PMA; $\mathrm{H}_{3}\left[\mathrm{PMo}_{12} \mathrm{O}_{40}\right]$ ) and ammonium reineckate salts (RN; $\left.\left[\mathrm{NH}_{4}\left(\mathrm{Cr}\left(\mathrm{NH}_{3}\right)_{2}(\mathrm{SCN})_{4}\right) \cdot \mathrm{H}_{2} \mathrm{O}\right]\right)$ were supplied from Fluka, Switzerland, and they were used as ion pairing agent.

\section{Apparatus}

Potential measurements were performed using Digital Multi-meter DT-9205A. Mercurymercury chloride double-junction reference electrode HANNA HI-5412 in conjugation with different surfactant ion selective electrode was used. pH measurements were done using HANNA, model 211, Romania. Elemental analysis for $\mathrm{C}, \mathrm{H}$ and $\mathrm{N}$ was carried out using Perkin-Elmer with monochrometer, cu-radiation $(\lambda=1.542 \mathrm{~A})$ at $40 \mathrm{Kv}, 35 \mathrm{~mA}$ and scanning speed $\mathrm{CHN}$ at Microanalysis Centers; Cairo University.

\section{Solutions}

Stock surfactant solution $\left(1.0 \times 10^{-2} \mathrm{~mol} \mathrm{~L}^{-1}\right)$ was prepared by dissolving $0.32238 \mathrm{~g}$ of TBAB in 100 $\mathrm{mL}$ double distilled water. The lower concentrated solutions $\left(1.0 \times 10^{-8}-1.0 \times 10^{-3} \mathrm{~mol} \mathrm{~L}^{-1}\right)$ were prepared by serial dilution from the stock solution. NaTPB solution $\left(1.0 \times 10^{-2} \mathrm{~mol} \mathrm{~L}^{-1}\right)$ was prepared by dissolving an accurate weighed amount of the substance in worm water, adjusted to $\mathrm{pH} 9$ by adding sodium hydroxide and completed to the desired volume with water. The resulting solution was standardized potentiometrically against standard $\left(1.0 \times 10^{-2} \mathrm{~mol} \mathrm{~L}^{-1}\right)$ thallium (I) acetate solution ${ }^{[5]}$. Aqueous solutions of PTA, PMA and RN were prepared using the analytical grade chemicals and the exact concentrations of these solutions were determined by the appropriate recommended methods ${ }^{[6-7]}$ and lower concentrated solutions were prepared by the appropriate dilutions ${ }^{[8]}$. All solutions must be protected from light by keeping them in dark coloured quickfit bottles during the whole work.

\section{Electrode preparations}

\section{Preparation of the ion exchanger}

The ion-pair compounds (IPs) were prepared by dropwise addition of ion pairing agent solutions including TPB, PMA, RN and PTA to $0.01 \mathrm{~mol} \mathrm{~L}^{-}$

${ }^{1} \mathrm{TBAB}$ solution with continuous stirring. The 
resulting precipitates formed, after digestion, were then filtered off on Whatman filter paper No.1 and washed several times with double distilled water. The compounds were left to dry at room temperature, then ground to fine powder. Small sample portions were sent for elemental analysis.

\section{Preparation of modified carbon paste electrode}

Carbon paste electrodes were prepared by mixing different amounts (3-20 mg) of IPs, carbon powder $(250 \mathrm{mg})$ and TCP plasticizer $(100 \mu \mathrm{L})$. Then this mixture was thoroughly mixed in the mortar until homogenization occurs. The resulting paste was then packed firmly into the hole of the electrode body. The surface of the resulting carbon paste electrode was polished using a filter paper to obtain new working surface and rinsed carefully with double distilled water ${ }^{[9]}$.

\section{Calibration of sensors}

Standard TBAB solutions having concentrations ranged from $1.0 \times 10^{-8}$ to $1.0 \times 10^{-2}$ mol L $\mathrm{L}^{-1}$ were prepared. The potential in $\mathrm{mV}$ of each sample solution was directly measured from the lowest to highest one using the proposed sensors. The negative logarithmic values of concentrations $(-\log [\mathrm{TBAB}])$ are plotted versus measured potentials and the slopes of the resulting calibration curves are calculated.

\section{Results and Discussion}

\section{Ion pair stoichiometric ratios}

Since [Tetra Butyl Ammonium] ${ }^{+}$is a cation, it has high affinity to form water insoluble ion-pair complexes with oppositely charged ions such as TPB, PTA, PMA, or RN. So in this study, different tetra-n-butyl ammonium-IPs were prepared and their stoichiometric ratios were determined from elemental analysis. The elemental analysis results showed that $\left[\mathrm{TBA}^{+}\right]$forms ion pair with $\left[\mathrm{TPB}^{-}\right]$ with calculated: $\% \mathrm{C}=85.47, \% \mathrm{H}=9.97$ and $\% \mathrm{~N}$ $=2.49$ and found: $\% \mathrm{C}=84.42, \% \mathrm{H}=10.03$ and $\% \mathrm{~N}=2.57$. For [TBA]: $[\mathrm{RN}]$ ion pair: $\% \mathrm{C}=41.47$, $\% \mathrm{H}=7.60$ and $\% \mathrm{~N}=16.93$ and found: $\% \mathrm{C}=$ $41.95, \% \mathrm{H}=7.42$ and $\% \mathrm{~N}=17.18$. This showed that TBAB forms ion pairs with NaTPB and RN in 1:1 stoichiometric ratio. For PMA and PTA, 3:1 [TBA]:[PMA] and [TBA]:[PTA] ion pairs were formed with calculated $\% \mathrm{C}=22.59, \% \mathrm{H}=4.24$ and $\% \mathrm{~N}=1.65$ (found: $\% \mathrm{C}=22.54, \% \mathrm{H}=4.42$ and $\% \mathrm{~N}=1.17)$ and $\% \mathrm{C}=15.98, \% \mathrm{H}=2.99$ and $\% \mathrm{~N}=2.32$ (found: $\% \mathrm{C}=15.86, \% \mathrm{H}=3.02$ and $\% \mathrm{~N}=2.34)$, respectively.

\section{Influence of the electrode composition}

Since factors such as sensitivity, linearity, detection limit... etc., for certain electrode are based on the electrode composition. Therefore, carbon paste electrodes were prepared containing different amounts and types of ion pairs and the effect of their concentrations and the influence of the nature of the ion pairs in the modified CPE composition was investigated. The carbon and plasticizer contents for MCPE were also studied. Also, the effect of other factors such as effect of $\mathrm{pH}$, selectivity, life time, temperature, response time and application were studied ${ }^{[10] .}$

\section{Electrode composition}

The effect of ion pairs type and content on the electrode composition was studied by preparing several electrodes containing different amounts of ion pairs and the best contents in case of CPEs were found to be $15 \mathrm{mg}$ TBA-TPB (electrode I), $15 \mathrm{mg}$ TBA-PTA (electrode II) and $6 \mathrm{mg}$ TBAPMA (electrode III) ion pairs, which give the best Nernstian slope values of $59.41 \pm 0.31,59.26 \pm 0.45$ and $59.95 \pm 0.35 \mathrm{mV}$ decade $^{-1}$, respectively. These fabricated electrodes exhibit suitable response to $\mathrm{TBAB}$ in a concentration range from $1.0 \times 10^{-6}$ to $1.0 \times 10^{-2} \mathrm{~mol} \mathrm{~L}^{-1}$ with lower detection limit of $1.0 \times 10^{-6} \mathrm{~mol} \mathrm{~L}^{-1}$ as shown in Table (1). On the other hand, the lower concentrations gave lower slope values while the higher content cause over saturation and unsatisfactory performance due to steric hindrance effects at the interface. The nature of the plasticizer is an important factor which affects on sensors performance. It is important for plasticizer to have certain properties and characteristics, such as having low vapor pressure, high molecular weight, high lipophilicity and high capacity for dissolving the substrate and other additives found in the matrix to prepare the sensors. In order to determine the suitable plasticizer, several CPEs were prepared with different plasticizer, and then the effect of their types was studied. It was found that electrode plasticized with TCP, FPNE and o-NPOE had the highest Nernstian slope because they improve flexibility and durability and more homogenized paste as shown in Table (2). We chose TCP because this type of plasticizer has low cost and more available ${ }^{[11]}$. 
Table 1: Effect of ion pair type and content on the performance of modified CPE sensors.

\begin{tabular}{|c|c|c|c|c|c|}
\hline \multirow[b]{2}{*}{$\begin{array}{l}\text { Ion } \\
\text { pair }\end{array}$} & \multicolumn{5}{|c|}{ Composition of CPEs } \\
\hline & $\begin{array}{l}\text { content } \\
(\mathrm{mg})\end{array}$ & $\begin{array}{l}\text { concentration } \\
\text { range }\left(\mathrm{mol} \mathrm{L}^{-1}\right.\end{array}$ & & $\begin{array}{c}\text { Slope }(\mathrm{mV} \\
\left.\text { decade }^{-1}\right)\end{array}$ & $\mathrm{R}^{2}$ \\
\hline \multirow{8}{*}{$\begin{array}{l}\text { [TBA- } \\
\text { TPB] }\end{array}$} & 3 & $\begin{array}{l}1.0 \times 10^{-6} \\
1.0 \times 10^{-2}\end{array}$ & - & $\begin{array}{ll}49.00 \quad \pm \\
1.77 & \end{array}$ & 0.9998 \\
\hline & 6 & $\begin{array}{l}1.0 \times 10^{-6} \\
1.0 \times 10^{-2} \\
\end{array}$ & & $\begin{array}{ll}49.50 \quad \pm \\
0.48 & \\
\end{array}$ & 0.9997 \\
\hline & 9 & $\begin{array}{l}1.0 \times 10^{-6} \\
1.0 \times 10^{-2}\end{array}$ & - & $\begin{array}{ll}56.70 \quad \pm \\
0.18 & \\
\end{array}$ & 0.9998 \\
\hline & 12 & $\begin{array}{l}1.0 \times 10^{-6} \\
1.0 \times 10^{-2}\end{array}$ & & $\begin{array}{ll}59.00 & \pm \\
0.52 & \end{array}$ & 0.9997 \\
\hline & 15 & $\begin{array}{l}1.0 \times 10^{-6} \\
1.0 \times 10^{-2}\end{array}$ & - & $\begin{array}{ll}59.41 \quad \pm \\
0.31 & \\
\end{array}$ & 1.000 \\
\hline & 20 & $\begin{array}{l}1.0 \times 10^{-6} \\
1.0 \times 10^{-2}\end{array}$ & & $\begin{array}{l}61.00 \\
0.71\end{array}$ & 0.9997 \\
\hline & 25 & $\begin{array}{l}1.0 \times 10^{-6} \\
1.0 \times 10^{-2}\end{array}$ & - & $\begin{array}{ll}49.60 \quad \pm \\
0.47 & \end{array}$ & 0.9995 \\
\hline & 30 & $\begin{array}{l}1.0 \times 10^{-6}- \\
1.0 \times 10^{-2}\end{array}$ & & $\begin{array}{ll}53.40 \quad \pm \\
0.2 & \\
\end{array}$ & 0.9998 \\
\hline \multirow{5}{*}{$\begin{array}{l}\text { [TBA- } \\
\text { PTA] }\end{array}$} & 3 & $\begin{array}{l}1.0 \times 10^{-6} \\
1.0 \times 10^{-2}\end{array}$ & - & $\begin{array}{l}46.45 \\
\pm 0.35 \\
\end{array}$ & 0.9996 \\
\hline & 6 & $\begin{array}{l}1.0 \times 10^{-6} \\
1.0 \times 10^{-2} \\
\end{array}$ & & $\begin{array}{ll}32.21 & \pm \\
0.16 & \\
\end{array}$ & 0.9996 \\
\hline & 9 & $\begin{array}{l}1.0 \times 10^{-6} \\
1.0 \times 10^{-2}\end{array}$ & - & $\begin{array}{ll}41.70 \quad \pm \\
0.28 & \\
\end{array}$ & 0.9996 \\
\hline & 12 & $\begin{array}{l}1.0 \times 10^{-6} \\
1.0 \times 10^{-2}\end{array}$ & - & $\begin{array}{l}24.12 \\
0.82\end{array}$ & 0.9998 \\
\hline & 15 & $\begin{array}{l}1.0 \times 10^{-6} \\
1.0 \times 10^{-2} \\
\end{array}$ & - & $\begin{array}{ll}59.26 \quad \pm \\
0.45 & \\
\end{array}$ & 1.000 \\
\hline \multirow{5}{*}{$\begin{array}{l}\text { [TBA- } \\
\text { PMA] }\end{array}$} & 3 & $\begin{array}{l}1.0 \times 10^{-6} \\
1.0 \times 10^{-2}\end{array}$ & - & $\begin{array}{l}30.55 \\
1.06 \\
\end{array}$ & 0.9997 \\
\hline & 6 & $\begin{array}{l}1.0 \times 10^{-6} \\
1.0 \times 10^{-2}\end{array}$ & - & $\begin{array}{ll}59.95 & \pm \\
0.35 & \end{array}$ & 1.000 \\
\hline & 9 & $\begin{array}{l}1.0 \times 10^{-6} \\
1.0 \times 10^{-2}\end{array}$ & - & $\begin{array}{l}24.70 \\
0.71\end{array}$ & 0.9999 \\
\hline & 12 & $\begin{array}{l}1.0 \times 10^{-6} \\
1.0 \times 10^{-2}\end{array}$ & - & $\begin{array}{ll}54.20 \quad \pm \\
0.14 & \\
\end{array}$ & 0.9999 \\
\hline & 15 & $\begin{array}{l}1.0 \times 10^{-6} \\
1.0 \times 10^{-2}\end{array}$ & - & $\begin{array}{l}40.35 \\
0.07 \\
\end{array}$ & 0.9999 \\
\hline \multirow{5}{*}{$\begin{array}{l}\text { [TBA- } \\
\text { RN] }\end{array}$} & 3 & $\begin{array}{l}1.0 \times 10^{-6} \\
1.0 \times 10^{-2} \\
\end{array}$ & - & $\begin{array}{ll}47.10 \quad \pm \\
0.28 & \\
\end{array}$ & 0.9999 \\
\hline & 6 & $\begin{array}{l}1.0 \times 10^{-6} \\
1.0 \times 10^{-2}\end{array}$ & - & $\begin{array}{l}34.30 \\
0.19\end{array}$ & 0.9998 \\
\hline & 9 & $\begin{array}{l}1.0 \times 10^{-6} \\
1.0 \times 10^{-2}\end{array}$ & - & $\begin{array}{ll}37.00 \quad \pm \\
0.28 & \\
\end{array}$ & 0.9997 \\
\hline & 12 & $\begin{array}{l}1.0 \times 10^{-6} \\
1.0 \times 10^{-2}\end{array}$ & - & $\begin{array}{l}30.00 \\
0.82 \\
\end{array}$ & 0.9998 \\
\hline & 15 & $\begin{array}{l}1.0 \times 10^{-6} \\
1.0 \times 10^{-2}\end{array}$ & - & $\begin{array}{ll}45.00 & \pm \\
0.45 & \end{array}$ & 0.9996 \\
\hline
\end{tabular}

Table 2: Effect of plasticizer on the performance of modified CPE.

\begin{tabular}{lcccc}
\hline plasticizer & $\begin{array}{c}c \\
\text { concentration } \\
\text { range }\left(\mathbf{m o l ~ L}^{-1}\right)\end{array}$ & \multicolumn{1}{c}{$\begin{array}{c}\text { Slope }(\mathbf{m V} \\
\left.\text { decade }^{-1}\right)\end{array}$} & $\mathbf{R}^{2}$ \\
\hline TCP & $1.0 \times 10^{-6}-1.0 \times 10^{-2}$ & $58.5 \pm 0.14$ & 0.9999 \\
\hline FPNE & $1.0 \times 10^{-6}-1.0 \times 10^{-2}$ & $59.40 \pm 0.36$ & 0.9998 \\
\hline NPOE & $1.0 \times 10^{-6}-1.0 \times 10^{-2}$ & $58.80 \pm 0.35$ & 0.9997 \\
\hline DOP & $1.0 \times 10^{-6}-1.0 \times 10^{-2}$ & $56.34 \pm 0.34$ & 0.9996 \\
\hline DBP & $1.0 \times 10^{-6}-1.0 \times 10^{-2}$ & $55.80 \pm 0.28$ & 0.9996 \\
\hline DOS & $1.0 \times 10^{-6}-1.0 \times 10^{-2}$ & $47.70 \pm 0.45$ & 0.9998 \\
\hline
\end{tabular}

\section{Electro analytical performance characteristics of} the sensors

The results presented in Table 3 showed that the prepared sensors can be successfully applied for the potentiometric determination of the surfactant under investigation with linear response in the concentration range of $1.0 \times 10^{-6}$ to $1.0 \times 10^{-2}$ mol L $\mathrm{L}^{-1}$ with nernstian slope values of $59.41 \pm$ $0.31,59.26 \pm 0.45$ and $59.95 \pm 0.35 \mathrm{mVdecade}^{-}$ ${ }^{1}$ for I, II and III electrodes respectively ${ }^{[12-13]}$.

Table (3): Critical response characteristics of I, II and III electrodes.

\begin{tabular}{|c|c|c|c|}
\hline Parameters & I & II & III \\
\hline Slope $\left(\mathrm{mVdecade} \mathrm{d}^{-1}\right)$ & $\begin{array}{ll}59.41 & \pm \\
0.31 & \end{array}$ & $\begin{array}{ll}59.26 & \pm \\
0.45 & \end{array}$ & $59.95 \pm 0.35$ \\
\hline $\begin{array}{l}\text { Correlation } \\
\text { coefficient, } r\end{array}$ & 0.9999 & 0.9996 & 0.9998 \\
\hline $\begin{array}{l}\text { Detection limit (mol } \\
\left.\mathrm{L}^{-1}\right)\end{array}$ & $1.0 \times 10^{-6}$ & $1.0 \times 10^{-6}$ & $1.0 \times 10^{-6}$ \\
\hline $\begin{array}{l}\text { Limit of quantitation } \\
\left(\mathrm{mol} \mathrm{L}^{-1}\right)\end{array}$ & $3.3 \times 10^{-6}$ & $3.3 \times 10^{-6}$ & $3.3 \times 10^{-6}$ \\
\hline Response time, (s) & 3 & 7 & 6 \\
\hline Working pH range & $3-8$ & $5-8$ & $5-9$ \\
\hline $\begin{array}{l}\text { Concentration } \\
\text { range, } \mathrm{mol} \mathrm{L}^{-1}\end{array}$ & $\begin{array}{l}1.0 \times 10^{-6}- \\
1.0 \times 10^{-2} \\
\end{array}$ & $\begin{array}{l}1.0 \times 10^{-6}- \\
1.0 \times 10^{-2} \\
\end{array}$ & $\begin{array}{l}1.0 \times 10^{-6}- \\
1.0 \times 10^{-2} \\
\end{array}$ \\
\hline $\begin{array}{l}\text { Isothermal } \\
\text { coefficient }\left(\mathrm{V} /{ }^{\circ} \mathrm{C}\right)\end{array}$ & $19.62 \times 10^{-4}$ & $\begin{array}{l}15.23 \\
\times 10^{-4} \\
\end{array}$ & $15.39 \times 10^{-4}$ \\
\hline Life span (Days) & 41 & 28 & 48 \\
\hline
\end{tabular}

\section{Dynamic response time}

For analytical applications, the response time of a fabricated sensor is of critical importance. The average time required for the electrode to reach a steady potential response within $\pm 1 \mathrm{mV}$ of the final equilibrium value after successive immersion of a series of TBAB solutions, each having a 10 -fold difference in concentration, $1.0 \times 10^{-6}$ to $1.0 \times 10^{-2} \mathrm{~mol} \mathrm{~L}^{-1}$ is investigated. The measurements of potential versus time were carried out with TBAB solutions from lower to higher concentrations ${ }^{[14-15]}$. The electrodes response time is found to be 3, 7 and 6 seconds over all linear concentration ranges for electrodes I, II, and III, respectively, as shown in Figure (1). 


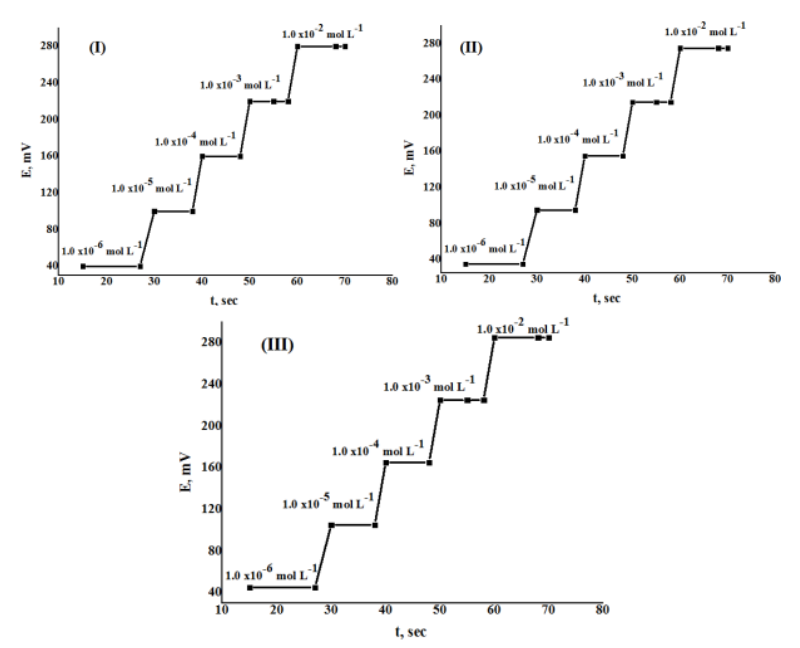

Figure (1): Response time effect on the performance of electrodes I, II and III.

\section{Effect of $p H$}

The influence of the hydrogen ion towards the emf of the electrodes was tested at $1.0 \times 10^{-3}$ and $1.0 \times 10^{-2} \mathrm{~mol} \mathrm{~L}^{-1}$ of the surfactant solution by varying the $\mathrm{pH}$ from 1.0 to 11.0 with diluted $\mathrm{HCl}$ or $\mathrm{NaOH}$. It is clear from Figure (2) that the electrodes have stable readings in the $\mathrm{pH}$ range 3.0 - 8.0, 5.0-8.0 and 5.0-9.0 for electrodes I, II and III, respectively. The change at higher $\mathrm{pH}$ could be the result of hydroxide precipitate formation, while in the low $\mathrm{pH}$ range; competitive proton binding is probably behind the increased potential values $^{[16-17]}$.
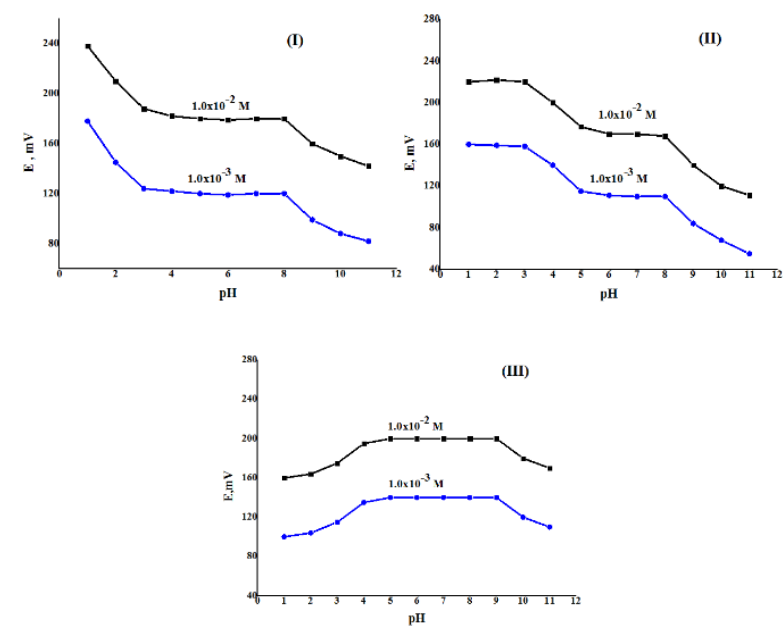

Figure (2). pH effect on the performance of electrodes I, II and III.

\section{Temperature Effect}

The influence of temperature on the characteristics of the electrodes was studied by recording the calibration graphs at different temperatures $\left(10,20,30,40,50\right.$ and $\left.60^{\circ} \mathrm{C}\right)$ where the standard cell potentials $\left(\mathrm{E}_{\text {cell }}^{\mathrm{o}}\right)$ were determined at these temperatures from the respective calibration graphs as the intercepts of these plots at surfactant concentration $=0$, and then plotted versus $(\mathrm{t}-25)$, where $\mathrm{t}$ is the temperature of the experiments. A straight-line plot was obtained and the slope represents the isothermal coefficient of the electrode according to the following equation:

$$
\mathrm{E}^{\mathrm{o}}{ }_{\text {ell }}=\mathrm{E}^{\mathrm{o}}{ }_{\text {cell }\left(25^{\circ} \mathrm{C}\right)}+(\mathrm{dE} / \mathrm{dt}) \operatorname{cell}(\mathrm{t}-25)
$$

The isothermal coefficients values were found to be $19.62 \times 10^{-4}, 15.23 \times 10^{-4}$ and $15.39 \times 10^{-4}$ $\left(\mathrm{V} /{ }^{\circ} \mathrm{C}\right)$ for electrodes I, II and III electrodes, respectively, which indicate that the proposed electrodes had high thermal stability within the used range of temperature ${ }^{[18-19]}$.

\section{Effect of foreign compounds on the electrodes selectivity}

The potentiometric selectivity coefficients $\left(K_{\text {Pot }}, \mathrm{j}\right)$ were determined according to IUPAC guidelines by examine influence of some inorganic cations on the TBAB-electrodes using the separate solutions (SSM) ${ }^{[20-21]}$. Surfactant primary ion (i) and interfering secondary ion (j) $\left(\mathrm{Na}^{+}, \mathrm{K}^{+}, \mathrm{Fe}^{2+}, \mathrm{Ni}^{2+}, \mathrm{Mn}^{2+}, \mathrm{Ca}^{2+}, \mathrm{Pb}^{2+}, \mathrm{Cd}^{2+}, \mathrm{Co}^{2+}\right.$, $\mathrm{Cu}^{2+}, \mathrm{Zn}^{2+}, \mathrm{Al}^{3+}$ and $\mathrm{Cr}^{3+}$ ) solutions were prepared having equal concentrations $\left(1.0 \times 10^{-3} \mathrm{~mol} \mathrm{~L}^{-1}\right)$. Their potentials Ei and Ej were measured using the proposed electrodes (I, II and III). Selectivity coefficients were calculated using the following equations ${ }^{[22-23]}$ :

$$
\log K_{i j}=\left[\left(E_{j}-E_{i}\right) / S\right]+\left[1 \pm\left(Z_{i} / Z_{j}\right)\right] \log \left[a_{i}\right]
$$

where $K^{\mathrm{Pot}}{ }_{\mathrm{i}, \mathrm{j}}$ is the potentiometric selectivity coefficient, $\mathrm{E}_{\mathrm{i}}$ is the potential measured in $1.0 \mathrm{x}$ $10^{-3} \mathrm{~mol} \mathrm{~L}^{-1} \mathrm{TBAB}, \mathrm{E}_{\mathbf{j}}$ the potential measured in $1.0 \times 10^{-3} \mathrm{~mol} \mathrm{~L}^{-1}$ of the interfering compound, $S$ the slope of the calibration plot, $a_{i}$ the activity of $T B A B$, and $Z_{i}$ and $Z_{j}$ are the charges on TBA and the interfering ion, respectively ${ }^{[24]}$. From Table 4 the selectivity coefficients values of the electrodes I, II and III reflect a very high selectivity of the investigated electrodes for the tetrabutylammonium cation $\left(\mathrm{TBA}^{+}\right)$. The inorganic cations do not interfere owing to the differences in ionic size, and consequently their mobilities and permeability, as compared with those of $\mathrm{TBA}^{+}$. 
Table 4: Potentiometric selectivity coefficients of the TBAB sensors.

\begin{tabular}{|c|c|c|c|}
\hline \multirow{2}{*}{$\begin{array}{c}\text { Interfering } \\
\text { ions (B) }\end{array}$} & \multicolumn{3}{|c|}{$K^{p o t} \mathbf{D , B}$} \\
\hline & I & II & III \\
\hline $\mathrm{Na}^{+}$ & $3.310 \times 10^{-4}$ & $1.259 \times 10^{-4}$ & $6.31010^{-4}$ \\
\hline $\mathbf{K}^{+}$ & $4.744 \times 10^{-4}$ & $5.843 \times 10^{-4}$ & $1.41310^{-4}$ \\
\hline $\mathrm{Fe}^{2+}$ & $3.339 \times 10^{-4}$ & $6.310 \times 10^{-4}$ & $4.46710^{-4}$ \\
\hline $\mathrm{Ni}^{2+}$ & $5.626 \times 10^{-4}$ & $1.413 \times 10^{-4}$ & $1.21210^{-5}$ \\
\hline $\mathrm{Mn}^{2+}$ & $2.215 \times 10^{-4}$ & $4.457 \times 10^{-4}$ & $1.64710^{-5}$ \\
\hline $\mathrm{Ca}^{2+}$ & $1.166 \times 10^{-4}$ & $6.644 \times 10^{-4}$ & $9.62410^{-6}$ \\
\hline $\mathbf{P b}^{2+}$ & $5.410 \times 10^{-4}$ & $5.222 \times 10^{-5}$ & $2.712 \times 10^{-4}$ \\
\hline $\mathbf{A L}^{3+}$ & $1.225 \times 10^{-4}$ & $1.001 \times 10^{-5}$ & $1.080 \times 10^{-4}$ \\
\hline $\mathrm{Cr}^{3+}$ & $1.267 \times 10^{-4}$ & $2.23210^{-4}$ & $1.212 \times 10^{-4}$ \\
\hline $\mathrm{Cd}^{2+}$ & $8.584 \times 10^{-4}$ & $1.088 \times 10^{-4}$ & $2.417 \times 10^{-4}$ \\
\hline $\mathrm{Cu}^{2+}$ & $6.777 \times 10^{-4}$ & $3.31210^{-4}$ & $3.043 \times 10^{-4}$ \\
\hline $\mathrm{Zn}^{2+}$ & $4.414 \times 10^{-4}$ & $8.487 \times 10^{-4}$ & $1.022 \times 10^{-4}$ \\
\hline $\mathrm{Co}^{2+}$ & $4.467 \times 10^{-4}$ & $1.043 \times 10^{-4}$ & $2.213 \times 10^{-5}$ \\
\hline
\end{tabular}

\section{Analytical applications}

In the proposed potentiometric method, TBAB is determined in spiked solution using direct calibration, the potentiometric titration and standard addition method ${ }^{[25]}$. In calibration method the emf resulted from immersing the prepared electrodes in conjunction with the double junction $\mathrm{Hg} / \mathrm{HgCl}_{2}$ reference electrode in the prepared solutions was determined, then the concentration of TBAB was calculated from the calibration graph of the corresponding electrode. In standard addition method, known small increments of unkown TBAB solution were added to $50 \mathrm{ml}$ aliquot samples of TBAB solutions of various concentrations. The change in $\mathrm{mV}$ reading was recorded for each increment and used to calculate the concentration of the TBAB sample solution. Each determination for each unknown

\begin{tabular}{|c|c|c|c|c|c|c|}
\hline Method & Electrode & $\begin{array}{c}\text { Taken } \\
\left(\mathrm{mg} \mathrm{mL}^{-1}\right) \\
\end{array}$ & $\begin{array}{c}\text { Found } \\
\left(\mathrm{mg} \mathrm{mL}^{-1}\right) \\
\end{array}$ & $\begin{array}{c}\text { Recovery } \\
\% \\
\end{array}$ & SD & RSD \% \\
\hline \multirow{6}{*}{$\begin{array}{c}\text { Standard } \\
\text { addition }\end{array}$} & \multirow{2}{*}{ I } & $3.2238 \times 10^{-3}$ & $3.3245 \times 10^{-3}$ & 103.12 & $1.0 \times 10^{-5}$ & 0.30 \\
\hline & & 0.32238 & 0.32358 & 100.37 & 0.001 & 0.31 \\
\hline & \multirow{2}{*}{ II } & $3.2238 \times 10^{-3}$ & $3.3185 \times 10^{-3}$ & 102.94 & 0.095 & 0.60 \\
\hline & & 0.32238 & 0.31888 & 98.91 & 0.004 & 1.25 \\
\hline & \multirow{2}{*}{ III } & $3.2238 \times 10^{-3}$ & $3.2005 \times 10^{-3}$ & 99.28 & $1.3 \times 10^{-5}$ & 0.41 \\
\hline & & 0.32238 & 0.31959 & 99.13 & 0.003 & 0.94 \\
\hline \multirow{9}{*}{ Calibration curve } & \multirow{3}{*}{ I } & $3.2238 \times 10^{-3}$ & $3.199 \times 10^{-3}$ & 99.99 & $1.0 \times 10^{-5}$ & 0.31 \\
\hline & & 0.03224 & 0.03224 & 100.00 & 0.000 & 0.00 \\
\hline & & 0.32238 & 0.31994 & 99.24 & 0.002 & 0.63 \\
\hline & \multirow{3}{*}{ II } & $3.2238 \times 10^{-3}$ & $3.2121 \times 10^{-3}$ & 99.64 & $1.7 \times 10^{-5}$ & 0.53 \\
\hline & & 0.03224 & 0.0332 & 102.98 & 0.001 & 3.01 \\
\hline & & 0.32238 & 0.32238 & 100.00 & 0.000 & 0.00 \\
\hline & \multirow{3}{*}{ III } & $3.2238 \times 10^{-3}$ & $3.2331 \times 10^{-3}$ & 100.29 & $2.0 \times 10^{-5}$ & 0.62 \\
\hline & & 0.03224 & 0.03300 & 102.36 & 0.001 & 3.03 \\
\hline & & 0.32238 & 0.31887 & 98.91 & 0.004 & 1.25 \\
\hline \multirow{3}{*}{$\begin{array}{c}\text { Potentiometric } \\
\text { titration }\end{array}$} & I & 3.2238 & 3.2238 & 100.00 & 0.000 & 0.00 \\
\hline & II & 3.2238 & 3.2248 & 100.03 & 0.001 & 0.03 \\
\hline & III & 3.2238 & 3.2238 & 100.00 & 0.000 & 0.00 \\
\hline
\end{tabular}

concentration was performed in constantly stirred solutions at fixed temperature. The concentration of the respective $\mathrm{TBAB}$ was calculated using standard addition method. It depends on the application of the following equation to each volume of the standard concentrated solution added to the unknown concentration ${ }^{[26]}$.

$$
\left.\mathrm{Cx}=\mathrm{CsVs} /\left[(\mathrm{Vx}+\mathrm{Vs}) \times 10^{\mathrm{n}(\Delta \mathrm{E} / \mathrm{s})}-\mathrm{Vx}\right)\right]
$$

Where $\mathrm{Cx}$ and $\mathrm{Vx}$ are the concentration and the volume of the unknown sample, respectively. Cs and $\mathrm{Vs}$ are the concentration and the volume of the standard, respectively. $\mathrm{S}$ is the slope of the calibration graph and $\Delta \mathrm{E}$ is the change in $\mathrm{mV}$ due to the addition of the standard. So the determination of the concentration depends mainly on $\Delta \mathrm{E}$, hence to obtain noticeable $\Delta \mathrm{E}$ we need to prepare higher concentration of the standard. The mean unknown concentration, $\mathrm{Cx}$, the mean recovery and the relative standard deviation values were calculated and the results obtained are given in Tables (5). Therefore, the studied sensors can be used successfully for the routine analysis of the TBAB surfactant in quality control laboratories. Aliquots of the TBAB solution containing $1.0 \times 10^{-2} \mathrm{~mol} \mathrm{~L}^{-1}$ surfactant solution were pipetted into a $10 \mathrm{~mL}$ beaker. NaTPB, PTA and RN were used as a titrant in the potentiometric titration. The potential values were plotted against the volume added of the titrant and the end points were determined from the S-shaped curves using the first derivative plots. The method was repeated several times to check the accuracy and precision of the proposed method. 


\section{Validation of the proposed potentiometric method}

The analytical method was validated according to the international conference for Harmonization (ICH) guidelines under the optimized experimental conditions by meaning: linearity, accuracy, precision, specificity, stability, limit of detection (LOD) and limit of quantification (LOQ) as shown in Table (3). The accuracy of the proposed method using ISE (modified with ion pairs) was investigated by the determination of TBAB surfactant in spiked samples prepared from serial concentrations of TBAB reference standards. The results summarized in Table (5), show high accuracy of the proposed method, as indicated by the percentage recovery values ${ }^{[27]}$. Precision is defined as the extent to which results agree with one another. In order to determine the precision of the proposed methods, solutions containing three different concentrations of TPAB were prepared and analyzed within the same day to evaluate repeatability (intra-day precision) and over five days to evaluate intermediate precision (inter-day precision) and the analytical results are summarized in Table (6). The low values of the relative standard deviation (\% RSD) also indicate the high precision and the good accuracy of the proposed methods ${ }^{[27]}$.

Table 6: Evaluation of accuracy and precision of the proposed electrodes.

\begin{tabular}{|c|c|c|c|c|c|c|c|c|c|}
\hline \multirow[b]{2}{*}{ Electrode } & \multirow{2}{*}{$\begin{array}{l}\text { Taken, } \\
\text { mg mL }^{-1}\end{array}$} & \multicolumn{4}{|c|}{ Intra-day } & \multicolumn{4}{|c|}{ Inter-day } \\
\hline & & $\begin{array}{c}\text { Found, mg } \\
\mathrm{mL}^{-1}\end{array}$ & $\begin{array}{c}\text { Recovery } \\
\%\end{array}$ & SD & $\begin{array}{c}\text { RSD } \\
\%\end{array}$ & $\begin{array}{c}\text { Found, mg } \\
\mathrm{mL}^{-1}\end{array}$ & $\begin{array}{c}\text { Recovery } \\
\%\end{array}$ & SD & RSD \% \\
\hline \multirow{3}{*}{ I } & $3.2238 \times 10^{-3}$ & $3.2248 \times 10^{-3}$ & 100.03 & $1.2 \times 10^{-5}$ & 0.37 & $3.1990 \times 10^{-3}$ & 99.23 & $2.5 \times 10^{-5}$ & 0.78 \\
\hline & 0.03224 & 0.03225 & 100.03 & $1.0 \times 10^{-5}$ & 0.03 & 0.03222 & 99.93 & $2.0 \times 10^{-5}$ & 0.06 \\
\hline & 0.32238 & 0.31900 & 98.95 & 0.003 & 0.94 & 0.32290 & 100.16 & 0.001 & 0.31 \\
\hline \multirow{3}{*}{ II } & $3.2238 \times 10^{-3}$ & $3.2238 \times 10^{-3}$ & 100.00 & 0.000 & 0.00 & $3.2221 \times 10^{-3}$ & 99.95 & $2.1 \times 10^{-5}$ & 0.65 \\
\hline & 0.03224 & 0.03223 & 99.97 & $1.0 \times 10^{-5}$ & 0.03 & 0.03227 & 100.09 & $3.0 \times 10^{-5}$ & 0.09 \\
\hline & 0.32238 & 0.32268 & 100.09 & 0.003 & 0.93 & 0.32238 & 100.00 & 0.000 & 0.00 \\
\hline \multirow{3}{*}{ III } & $3.2238 \times 10^{-3}$ & $3.2238 \times 10^{-3}$ & 100.00 & 0.000 & 0.00 & $3.2129 \times 10^{-3}$ & 99.66 & $3.0 \times 10^{-5}$ & 0.93 \\
\hline & 0.03224 & 0.03227 & 100.09 & $3.0 \times 10^{-5}$ & 0.09 & 0.03228 & 100.12 & $4.0 \times 10^{-5}$ & 0.12 \\
\hline & 0.32238 & 0.32238 & 100.00 & 0.000 & 0.00 & 0.32238 & 100.00 & 0.000 & 0.00 \\
\hline
\end{tabular}

\section{Conclusion}

From the above study we found that the proposed electrodes as TBAB selective sensors exhibited fast, stable, reproducible and selective response over a perceptible spacious concentration range. Analytical applications of the sensors confirm that they offer promise for perpetual and routine analysis of $\mathrm{TB} A B$ in various samples.

\section{References}

http://csrg.ch.pw.edu.pl/tutorials/ise/,2005.

Buck, RP; Lindner, E, Anal. Chem., 2001; 73: 88A.

Walden, M. and Mariahazey, A. (1971) U.S Patent 3,625,891, assigned to Armour Industrial Company.

http://www.sciencelab.com/msds.php?msdsId=992519 0

Vytras, K, Ion-Sel. Electrodes Rev., 1985; 7: 77.

Hayashi, H; Moffat, JB, Talanta, 1982; 29: 943.

Towns, TG, Anal. Chem., 1986; 58: 223.

Selig, W, Talanta, 1980; 27: 914.
Svancara, M; Vytras, K, Chem. Listy, 1994; 88: 138.

Eman.Y.Z. Farag; Gehad.G.M:. El-Sayed. W. G, Bioelectrochemistry 82 (2011) 79.

Huang .M..R; Ding, X.-G. Li, Combinatorial screening of potentiomet- ric $\mathrm{Pb}(\mathrm{II})$ sensors from polysulfoaminoanthraquinone solid IONOPHORE, ACS Comb. Sci. 16 (2014) 128-138.

Buck.R.P; Lindner .E; Pure Appl. Chem. 66 (1994) 2527.

Erdem A; Ozsoz. M; Kirilmaz. L; Kilinc .E ; Dalbasti .T, Electroanalysis 9 (1997) 932.

Kalcher .K; Svancara. I; Encyclopedia of Sensors, American Scientific Publishers, Stevenson Ranch. 4 (2006) 283-430.

Vytras. K ; Jezkova. J; V.Dlabka;Sci. Pap. Univ. Pardubice, Ser. A, 3, 1997, p. 307.

Othman. A.M, N. . Rizk; M.H, El-Shahawi .M.S., Anal. Chim. Acta 515 (2004) 303.

Hassan. S.S.M; Elnemma. E.M.; Mahmoud W.H.; Mohammed A.H.K., J. Appl. Electrochem. 36 (2006) 139.

Ghoreishi. S.M; Behpour. M; Nabi. M; Sens. Actuators B 113 (2006) 963.

Antropov .L.I; Theoretical Electrochemistry, Mir Publisher, Moscow, 1977. 
Othman. A.M, N. . Rizk; M.H, El-Shahawi .M.S Polymer membrane sensors for sildenafil citrate (Viagra) determination in pharmaceutical preparations, Anal. Chim. Acta 515 (2004) 303309.

Hassan.S.S.M; Elnemma. E.M; Continuous potentiometric monitoring of viagra (sildenafil) in pharmaceutical preparations using novel membrane sensors, J. Appl. Electrochem. 36 (2006) 139-146.

Ghoreishi.S.M; Behpour .M, A novel naphazolineselective membrane sensor and its pharmaceutical applications, Sens. Actuators B 113 (2006) 963
969.

Antropov .L.I., Theoretical Electrochemistry, Mir Publisher, Moscow, 1977.

Hassan.S.S.M.; Mahmoud W.H; Othman A.M; Talanta 44 (1997) 1087 (and references cited therein).

Okeri, HA; Alonge, PO; Etareri, E, Int. J. Health. Res., 2008; 1(1): 21-26.

Ghoreishi, SM; Behpour, M; Nabi, M, Sens. and Act. B Chem., 2006; 113(2): 963-969.

Gumustas, M; Ozkan, AS, The Open Anal. Chem. J., 2011; 5: 1 . 